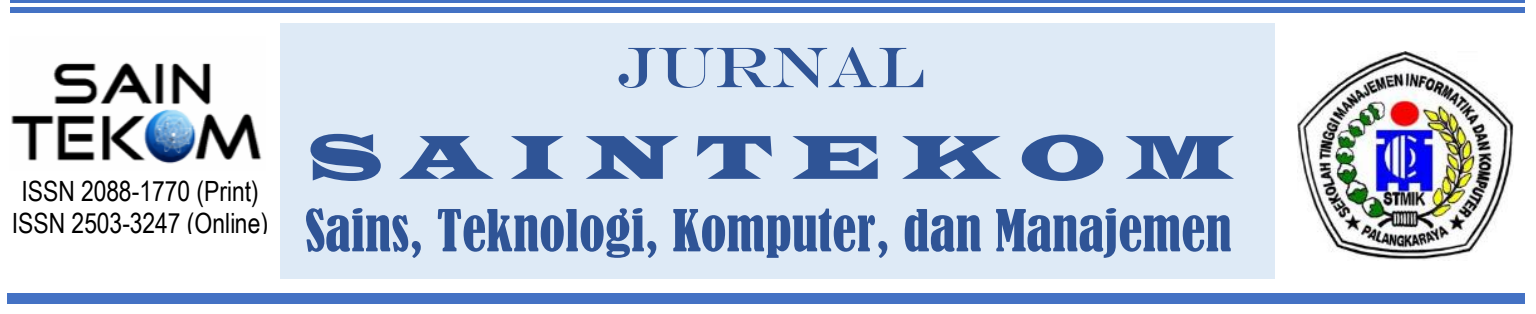

\title{
SISTEM INFORMASI GEOGRAFIS UMKM BAHAN MAKANAN DAN PANGAN BAGI MASYARAKAT DALAM MENGHADAPI NEW NORMAL
}

\author{
Andini Dani Achmad 1, *Abdul Samad Arief ${ }^{2}$, Diel Din ${ }^{3}$, Muh. Dzulfadli Rusli 4 \\ dan Farhan Muhammad Rajib ${ }^{5}$ \\ 1,3,4,5)Departemen Teknik Elektro Fakultas Teknik Universitas Hasanuddin \\ Jl. Malino Km. 6 Bontomarannu Kabupaten Gowa Sulawesi Selatan \\ 2) Jurusan Manajemen, Fakultas Ekonomi dan Ilmu-Ilmu Sosial Universitas Fajar \\ Jl. Prof. Abdurahman Basalamah No.101, Karampuang, Kec. Panakkukang, Kota \\ Makassar, Sulawesi Selatan \\ Email: andini.achmad@unhas.ac.id, abdulsamad@unifa.ac.id, \\ diel.din.unhas@gmail.com,dzulfadlirusli@gmail.com,frhanrjb0406@gmail.com
}

\section{ABSTRACT}

This study aims to build a web-based geographic information system for food material and foodstuffs UMKMs in Makassar City to disseminate geographic information that can be accessed anytime and from anywhere. The system is designed using a sequential waterfall method. Data sourced from the Makassar City Cooperatives and UKMs Office, field surveys, and interviews with UMKM owners. This system were developed to assist the government in providing information to the public about the location and distribution of UMKMs and other related information in dealing with the new normal, because it can visualize the distribution in Makassar City well. The system has been successfully developed through public testing, the average values of which are user objectives (4.18), information quality (4.13), and System Quality (4.12).

Keywords: Geographic Information System, Makassar City Cooperatives and UKMs Office, UMKM food material and foodstuffs

\section{ABSTRAK}

Penelitian ini bertujuan untuk membangun sistem informasi geografis berbasis web UMKM bahan makanan dan pangan di Kota Makassar dalam rangka penyebaran informasi geografis yang dapat diakses kapan dan dari mana saja. Sistem dirancang menggunakan metode waterfall yang bersifat sequential. Data bersumber dari Dinas Koperasi dan UKM Kota Makassar, survei lapangan, serta wawancara kepada pemilik UMKM. Sistem ini dibuat untuk membantu pemerintah dalam memberikan informasi kepada masyarakat tentang lokasi dan penyebaran UMKM dan informasi terkait lainnya dalam menghadapi new normal, karena mampu memvisualisasikan sebarannya dengan baik di kota Makassar. Sistem telah berhasil 
dikembangkan melalui pengujian publik, yang nilai rata-ratanya adalah Kepuasan Pengguna (4.18), kualitas informasi (4.13), dan Kualitas Sistem (4.12).

Kata kunci : sistem informasi geografis, Dinas Koperasi dan UKM Kota Makassar, UMKM bahan makanan dan pangan

\section{PENDAHULUAN}

Resesi dunia yang sangat berat terjadi saat ini karena pandemi COVID19 (Sharma et al. 2020). Ekonomi global berhenti pada bulan Maret hingga Juni dan hal ini belum pernah terjadi sebelumnya (Kuckertz et al. 2020). Virus ini kenyataannya dapat mengancam perekonomian dunia dan tentu saja membahayakan sebagian besar sistem yang ada (García-Vidal et al. 2020), termasuk usaha mikro kecil dan menengah (UMKM). Banyak negara yang terancam UMKM-nya karena sektor ini adalah generator penting bagi pertumbuhan ekonomi dan lapangan kerja. Dalam keadaan normal, kontribusi UMKM terhadap perekonomian nasional sangat besar. UMKM dalam hal penyerapan tenaga kerja mampu menyedot lebih dari 96 persen dari 170 juta tenaga kerja, kemudian ekonomi Indonesia sendiri 80 persennya disokong oleh konsumsi dalam negeri. Asosiasi Usaha Mikro, Kecil, dan Menengah Indonesia (Akumindo) mencatat bahwa pada tahun 2019, UMKM berkontribusi terhadap produk domestik bruto (PDB) Indonesia mencapai 65 persen atau sekitar Rp 2.394,5 triliun (Syahputra et al. 2020). Namun UMKM amat rentang terhadap guncangan eksternal (Eggers, 2020) sehingga di saat pandemi datang, keputusan pemerintah yang melakukan penutupan usaha dalam beberapa waktu untuk mencegah penyebaran COVID-19 merupakan salah satu tantangan terbesar pelaku bisnis UMKM dan hal ini tentu saja sulit bagi mereka (García-Vidal et al. 2020).

Krisis COVID-19 memberikan beban ekonomi terburuk kepada UMKM dan mereka berada di bawah tekanan berat untuk mencoba memahami dampak krisis tersebut, dan tidak tahu bagaimana masa depan mereka dan Langkah-langkah apa saya yang akan mereka lakukan (Kottika et al. 2020). Dampak dari wabah ini sudah dapat kita saksikan, Sebagian besar dari mereka bahkan berada di tahap kehancuran dan Sebagian lagi berjuang untuk bertahan hidup dengan melakukan keputusan sebaik mungkin seperti (1) menutup sementara dengan 
harapan setelah melewati batas waktu tertentu keadaan sudah membaik (2) melakukan investasi dengan merubah core bisnis dalam menghadapi cepatnya perubahan lingkungan (García-Vidal et al. 2020).

Persoalannya adalah pelaku bisnis UMKM memiliki sumber dana yang minim. Jika mereka menggunakan dana tersebut untuk keberlanjutan usahanya, maka kemungkinan aliran pendapatan mereka menjadi nol dan dalam waktu yang singkat mereka akan kehabisan uang (Brown dan Rocha, 2020), yang berarti mereka tutup. Oleh karena itu penting bagi pemerintah, akademisi, peneliti, dan pelaku usaha itu sendiri untuk dapat menemukan prioritas dalam mengelola jenis bisnis ini dan mendorongnya untuk maju di saat seperti sekarang ini (García-Vidal et al. 2020). Berdasarkan data UMKM dan usaha besar (UB), jumlah usaha besar 5.460 unit, usaha menengah 58.627 unit, usaha kecil 757.090 unit, serta usaha mikro 62.106.900 unit, dan sebanyak 98 persen dari total jumlah UMKM itu terdampak pandemi (Utami dan Sumardi, 2020).

UMKM yang merupakan bagian penting dari perekonomian negara berjuang keras untuk tetap bertahan meskipun di saat bersamaan juga berada di bawah tekanan ekstrem yang merasakan tekanan ekonomi di tengah COVID-19. Para pelaku bisnis UMKM harus membuat keputusan yang belum pernah hadapi sebelumnya, itulah sebabnya penting untuk membicarakan tentang apa yang perlu dilakukan untuk mengelola melalui krisis ini, tidak hanya kinerja bisnis yang dipertaruhkan tetapi juga kelangsungan hidup usahanya (García-Vidal et al. 2020).

Namun demikian, mengingat ukuran UMKM yang lebih kecil maka mereka cenderung lebih fleksibel ketika ancaman dan peluang muncul di lingkungan mereka (Osiyevskyy, 2020). Semakin kecil organisasi maka semakin dekat pembuat keputusan dengan pelanggan mereka dan juga dengan pemangku kepentingan lainnya yang memfasilitasi informasi pasar yang bermanfaat agar mereka dapat fokus ke arah yang lebih baik (Eggers, 2020), termasuk dalam menghadapi tatanan kehidupan normal yang baru atau new normal akibat pandemi COVID-19. UMKM harus melakukan penyesuaian kembali, serta meningkatkan strategi dan perilaku mereka yang sesuai dengan lingkungan untuk memastikan kelangsungan bisnis (Brown dan Rocha, 
2020). Hasil riset membuktikan bahwa manajemen dan orientasi pasar yang baik berdampak positif pada kinerja UMKM di saat krisis (Kottika, 2020).

Pemerintah saat ini sudah mulai menerapkan kondisi new normal, dengan pertimbangan bahwa perekonomian negara harus tetap berputar, sehingga diharapkan banyak sektor dapat tetap atau kembali berjalan dengan mengikuti imbauan protokol kesehatan yang telah ditetapkan. Sektor makanan dan minuman berkontribusi besar untuk dijadikan usaha, selalu menunjukkan pertumbuhan positif, dan memberikan kontribusi terbesar pada pertumbuhan non migas nasional. Peluang usaha industri makanan dan minuman memiliki prospek yang menjanjikan dibanding bidang usaha lainnya (Aadila et al. 2021), dan UMKM yang bergelut di sektor ini yang dapat bertahan di era pandemi (Aryansah dan Mirani, 2020). Hal ini terjadi karena masyarakat selalu membutuhkan persediaan makan dan minum sehingga sektor ini tidak akan pernah kehilangan konsumen. Selain itu bisnis ini hanya membutuhkan tenaga kerja yang tidak terlalu banyak serta modal yang relatif kecil, namun dengan perputaran arus kas yang cepat dan margin laba yang besar.

Dinas Koperasi dan UMKM Kota Makassar yang memiliki tugas dalam melakukan pengembangan dan pembinaan UMKM untuk wilayah Kota Makassar, telah melakukan berbagai kegiatan yang di antaranya adalah melakukan pendataan UMKM yang kemudian disosialisasikan ke masyarakat. Dari hasil riset awal yang dilakukan Dinas koperasi dan UMKM Kota Makassar, diperoleh permasalahan yaitu tidak tersedianya informasi yang baik kepada masyarakat tentang UMKM termasuk usaha penyedia Bahan makanan dan pangan sehingga masyarakat sulit mengetahui lokasi dari UMKM tersebut dalam wilayah Kota Makassar. Berdasarkan informasi yang ada maka diperlukan solusi dalam menjawab permasalahan tersebut. Sistem informasi geografis (SIG) adalah salah satu solusi yang dapat membantu Dinas koperasi dan UMKM Kota Makassar untuk memberikan informasi tentang lokasi UMKM bahan makanan dan pangan sehingga dapat memudahkan masyarakat untuk mengetahui lokasinya serta informasi lain yang terkait dalam wilayah Kota Makassar. 
SIG adalah komponen yang terdiri dari perangkat lunak, perangkat keras, data geografis, serta sumber daya manusia yang secara Bersama-sama bekerja dengan efektif untuk memasukkan, memperbaiki, menyimpan, mengelola, memperbaharui, menganalisa, mengintegrasikan, memanipulasi, dan menampilkan data dalam suatu informasi berbasis geografis (Pakaya et al. 2020). SIG dapat memberikan informasi tentang UMKM bahan makanan dan pangan yang berbentuk map sehingga tidak membosankan dan lebih menarik. SIG akan memberikan tampilan mengenai titik lokasi usaha dan datadata usaha lainnya seperti kegiatan usaha, nama usaha, jenis usaha, produk usaha, alamat usaha, serta keterangan lainnya yang berbentuk visual, sehingga masyarakat akan lebih mudah dalam melihat persebarannya berbentuk tampilan grafis dan juga merupakan solusi bagi para pelaku usaha UMKM khususnya bahan makanan dan pangan untuk dapat lebih dikenal oleh masyarakat (Noviyanti et al. 2020).

Tujuan penelitian ini adalah untuk: (1) menganalisis kebutuhan pemerintah kota Makassar khususnya Dinas Koperasi dan UKM pada sistem informasi terkait informasi posisi atau lokasi UMKM Bahan makanan dan pangan untuk dapat di akses oleh masyarakat dengan mudah merancang, membangun, dan menguji sistem informasi geografis berbasis Web yang dapat digunakan untuk menyediakan informasi posisi atau lokasi tentang UMKM bahan makanan dan pangan, dan informasi lainnya yang terkait.

Melalui penelitian ini diharapkan akan terbentuk informasi yang dibutuhkan mengenai lokasi UMKM bahan makanan dan pangan serta informasi lain dari UMKM tersebut melalui pengembangan SIG berbasis web dalam membantu masyarakat mengakses UMKM terdekat di wilayah geografis tertentu untuk keperluan sehari-hari, dan juga sebagai sistem pendukung keputusan bagi pemerintah dalam mengakses UMKM tersebut untuk keperluan pengembangan UMKM di masa yang akan datang. SIG adalah sistem berbasis komputer yang mampu menangkap, menyimpan, menganalisis, dan menampilkan informasi yang direferensikan secara geografis; yang diidentifikasi menurut lokasi. (Susanty et al. 2015). Dengan demikian urgensi penelitian ini adalah pengembangan sistem informasi 
geografis (SIG) dalam bentuk web untuk membantu pemerintah dan masyarakat dalam mengakses UMKM bahan makanan dan pangan untuk memenuhi tujuan masing-masing di wilayah Kota Makassar.

Kontribusi dari penelitian ini adalah adanya pengambilan keputusan berbasis SIG tentang UMKM bahan makanan dan pangan di kota Makassar, dan cara informasi geografis digunakan dalam berbagai model penyajian.
Informasi yang diperoleh dari SIG sebagai salah satu sumber informasi tentang UMKM bahan makanan dan pangan yang akan mudah dipahami oleh masyarakat dan pemerintah.

\section{METODE}

Model pengembangan aplikasi yang digunakan adalah metode Waterfall (Pressman, 2012) yaitu sebuah metode pengembangan software yang bersifat sequential seperti terlihat pada Gambar 1.

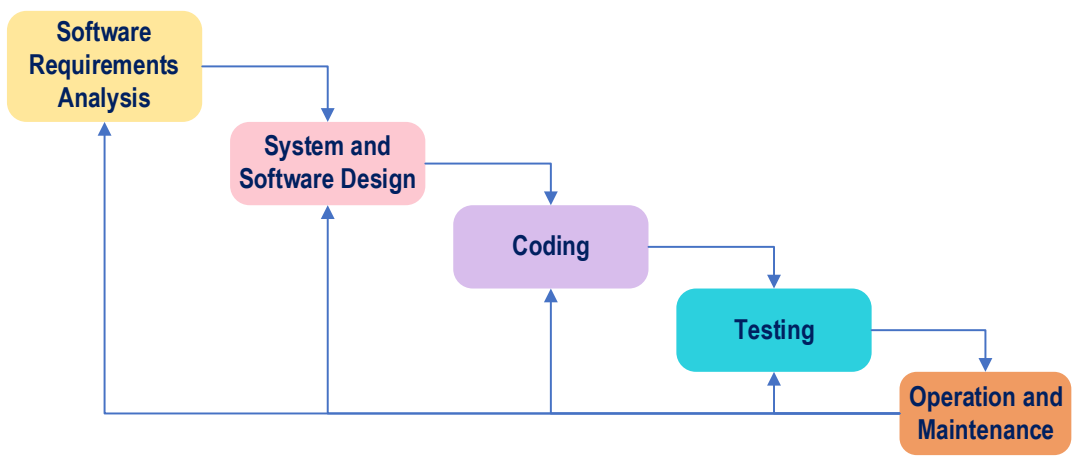

Gambar 1 Metode Waterfall

(Sumber: Pressman, 2012)

Pada tahap awal yaitu Software Requirements, dilakukan pencarian data maupun software dan hardware yang berkaitan dengan sistem yang akan dibuat, antara lain dengan mencari sumber-sumber atau literatur yang dapat berupa jurnal ilmiah, buku, dan berbagai sumber informasi lainnya yang mendukung penelitian ini. Hasil analisis diperoleh bahwa belum tersedianya sistem informasi geografis UMKM bahan makanan dan pangan di Kota
Makassar, sehingga diusulkan sebuah sistem informasi geografis yang mampu memberikan kemudahan bagi masyarakat dalam mengakses data dan lokasi UMKM bahan makanan dan pangan. Sistem informasi ini juga merupakan salah satu bentuk dukungan pemerintah Kota Makassar untuk pemulihan UMKM untuk menghadapi new normal, apalagi perannya yang strategis bagi perekonomian nasional. 
Selanjutnya adalah tahap perancangan sistem. Tahap ini membutuhkan data spasial berupa peta digital kota Makassar dengan skala 1: 5000 dan data non spasial berupa data usaha UMKM bahan makanan dan pangan di Makassar dengan melakukan survei lapangan. Dari survei lapangan diperoleh data primer berupa koordinat lokasi, verifikasi lokasi data yang ada, dan atribut yang akan digunakan dalam

SIG UMKM bahan makanan dan pangan. Skema penggunaan data sebagai informasi yang akan ditampilkan pada sistem ini diperlihatkan pada Gambar 2.

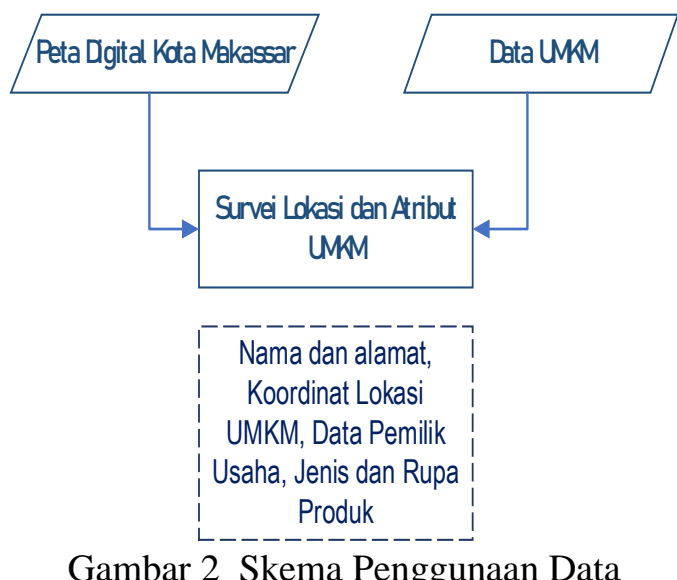

Gambar 2 Skema Penggunaan Data

Dalam tahapan perancangan sistem dilakukan: desain perancangan sistem (Input dan Output System), desain basis data (Entity Relationship Diagram), dan desain antarmuka. Desain perancangan sistem diperlihatkan melalui context diagram seperti pada Gambar 3.

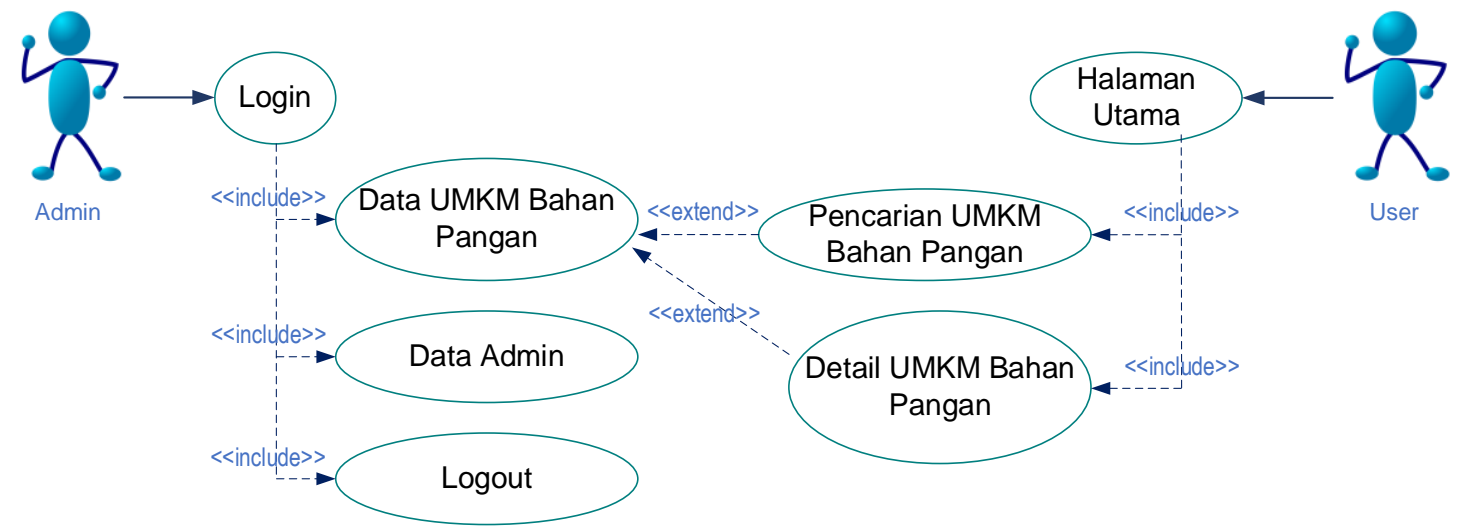

Gambar 3 Context Diagram

Berikutnya adalah tahap coding, yaitu tahap menerjemahkan desain perangkat lunak menggunakan bahasa pemrograman PHP dan database MySQL. Dalam bahasa pemrograman PHP yang digunakan dalam pengembangan aplikasi ini, database terdiri dari sekumpulan folder yang berisi file php yang menyediakan class library, helper, plugin dan lain-lain.

Tahap selanjutnya adalah testing, yaitu tahap dengan melakukan uji coba pada sistem yang telah dibuat. Uji coba yang dilakukan berupa 
verifikasi dan validasi. Verifikasi dilakukan untuk mengetahui apakah sistem yang dibuat sudah benar dan bebas dari kesalahan. Tahap terakhir adalah maintenance, yang merupakan tahap akhir dari perancangan sebuah sistem, perangkat lunak akan mengalami beberapa perubahan dan atau penambahan sesuai dengan permintaan user dalam penggunaannya.

\section{HASIL DAN PEMBAHASAN}

\subsection{Hasil}

Penelitian ini menggunakan Metode waterfall yaitu metode yang pembuatan sistem yang dibuat dengan terstruktur dan sistematis (berurutan) sesuai siklus pengembangan yang ada. Metode ini memungkinkan setiap tujuan persyaratan, dan spesifikasi dari sistem didefinisikan dengan detail pada tahap awal (persyaratan dan desain) sebelum masuk pada tahap proses (implementasi), oleh karena itu metode ini sesuai untuk memecahkan masalah yang dikemukakan di sini.

Penelitian ini bertujuan untuk merancang, membangun, dan menguji sistem informasi geografis berbasis Web yang dapat digunakan untuk menyediakan informasi posisi atau lokasi tentang UMKM bahan makanan dan pangan, dan informasi lainnya yang terkait.

\subsection{Pembahasan}

Dalam penelitian ini, SIG dirancang untuk membentuk sebuah sistem yang dapat memudahkan masyarakat menemukan UMKM Bahan Makanan untuk memenuhi kebutuhannya setiap hari. Setelah memperoleh data dari Dinas Koperasi dan UKM, jumlah UMKM yang ada di kota Makassar sebesar 13.277 UMKM pada tahun 2019. Setelah melakukan pengecekan, baik dari data yang ada maupun survei ke lokasi sesuai dengan data tersebut, maka hanya ada 39 UMKM yang khusus mengelola usaha bahan makanan, jumlah tersebut di luar usaha-usaha yang terletak pada pasarpasar tradisional yang tersebar di seluruh kota Makassar.

Penelitian yang dilakukan dalam upaya untuk menganalisis kebutuhan pemerintah kota Makassar khususnya Dinas Koperasi dan UKM pada sistem informasi terkait informasi posisi atau lokasi UMKM Bahan makanan dan pangan untuk dapat di akses oleh masyarakat dengan mudah berupa sistem informasi geografis UMKM bahan makanan dan pangan yang diimplementasikan pada basis website. 
Fitur-fitur penting yang terdapat pada aplikasi ini adalah : menu Beranda, menu Daftar Umum, menu Peta Persebaran UMKM, dan menu Tentang.
Pada menu Daftar UMKM terdapat detail setiap UMKM yang terdata beserta dengan lokasinya dalam bentuk peta.

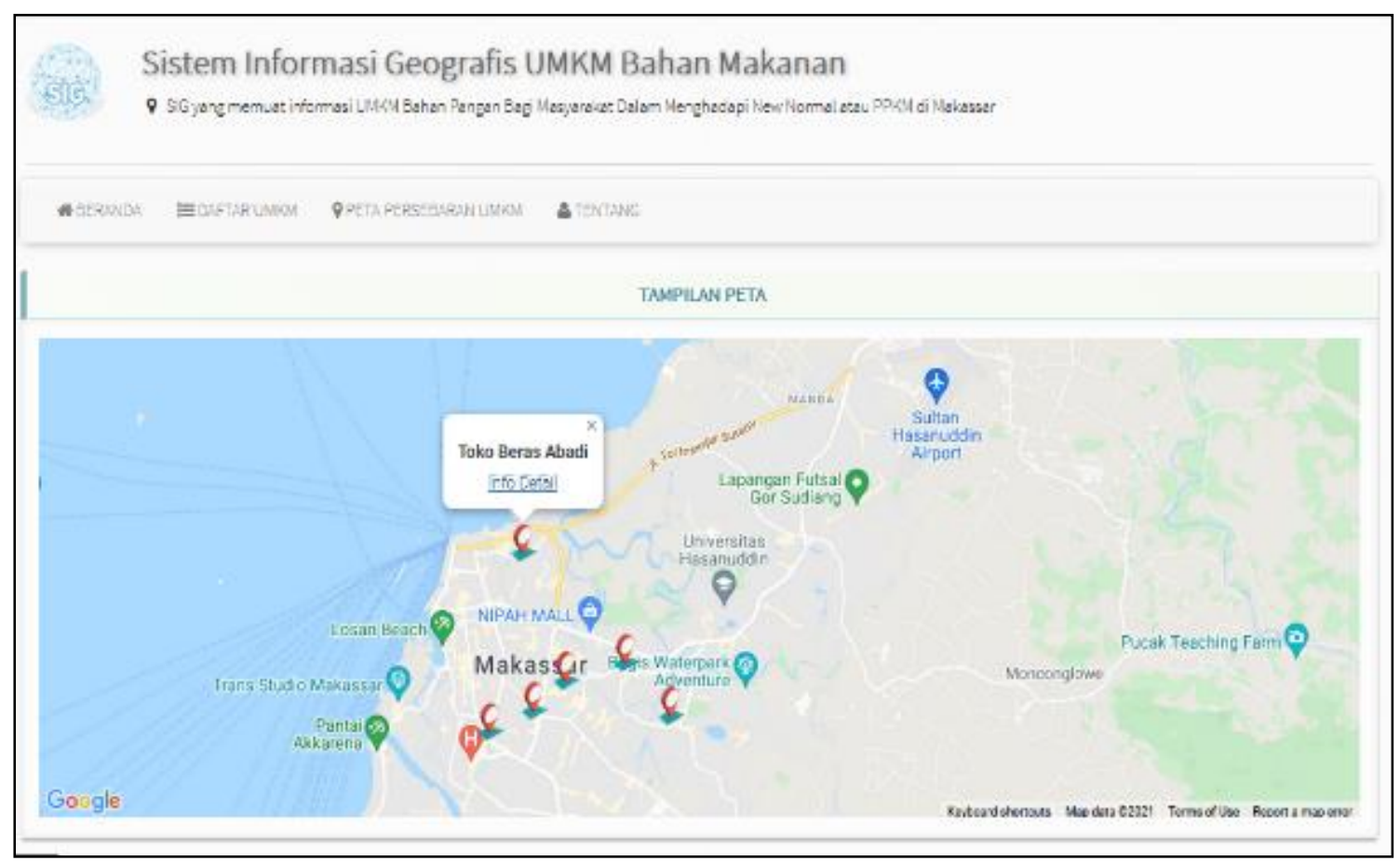

Gambar 4 Sistem Informasi Geografis UMKM Bahan Makanan dan Pangan Kota Makassar

Gambar 4 menunjukkan hasil pengembangan visualisasi sebaran UMKM Bahan makanan dan pangan menggunakan Sistem Informasi Geografis berbasis web, yang dikembangkan dengan menggunakan bahasa pemrograman PHP dan database MySQL. Dalam bahasa pemrograman PHP yang digunakan dalam pengembangan aplikasi ini, databasenya terdiri dari sekumpulan folder yang berisi file php yang menyediakan class library, helper, plugin dan lain-lain. Setelah itu, peneliti kemudian melakukan uji aplikasi publik. Uji ini dilakukan kepada responden yang terpilih yang berjumlah 137 orang dengan metode simple random sampling. Untuk uji aplikasi publik tersebut, parameter yang digunakan terdiri dari tiga pernyataan yang diadopsi dari literatur (Wibowo dan Selviyanti, 2021) yaitu Kepuasan Pengguna, kualitas informasi, dan Kualitas Sistem. Semua pernyataan diukur dengan menggunakan skala likert lima poin yaitu 1. sangat tidak baik, 2. tidak baik, 3. agak baik, 4. baik, 
dan 5. sangat baik. Analisis yang digunakan adalah mean atau rata-rata dari setiap pernyataan tersebut yang hasil pengujiannya dapat dilihat ditunjukkan pada Tabel 1.

Tabel 1 Hasil Pengujian Sistem

\begin{tabular}{|c|c|}
\hline Indikator & Hasil \\
\hline Kepuasan Pengguna & 4.18 \\
\hline Kualitas Informasi & 4.13 \\
\hline Kualitas Sistem & 4.12 \\
\hline
\end{tabular}

Hasil pengujian pada tabel 1 menggambarkan tanggapan dari 137 responden atas pernyataan tentang kepuasan pengguna, kualitas informasi, dan kualitas sistem pada aplikasi tersebut. Setiap responden memberikan penilaian dengan memilih skala antara 1 (sangat tidak baik) sampai dengan 5 (sangat baik) untuk setiap pernyataan, yang kemudian seluruh penilaian dari tiap pernyataan dari seluruh responden tersebut kemudian dihitung dengan menggunakan analisis Mean atau ratarata. Nilai yang diperoleh untuk setiap pernyataan pada tabel 1 berada pada skala 4 (baik) dan 5 (sangat baik), hasil ini merupakan representasi dari persepsi responden tentang Sistem Informasi Geografis UMKM Bahan Makanan dan Pangan Kota Makassar.

Sistem informasi ini diharapkan dapat memudahkan pemerintah dan masyarakat untuk mengakses UMKM bahan makanan dan pangan dengan mengetahui keberadaan lokasi serta informasi awal tentang UMKM yang terdata pada Dinas Koperasi dan UMKM Kota Makassar.

\section{SIMPULAN}

Pengembangan SIG berbasis Web untuk pemilihan UMKM bahan makanan dan pangan disajikan dalam artikel ini. Pemodelan yang ditawarkan oleh GIS secara langsung dapat diterapkan untuk memahami lokasi setiap UMKM tersebut. Metodologi waterfall digunakan sebagai alat untuk pengembangan GIS. Pengujian aplikasi publik dilakukan untuk memverifikasi bahwa SIG yang diusulkan memenuhi persyaratan yang ditentukan. Hasil pengujian dengan menggunakan tiga indikator yaitu yang diukur dengan skala likert pada 137 responden menunjukkan bahwa Kepuasan Pengguna, kualitas informasi, dan Kualitas Sistem berada pada kategori antara baik dan sangat baik.

Keterbatasan yang ada pada penelitian ini adalah (1) Data yang tersedia di pemerintah daerah tidak lengkap, tidak akurat serta tidak up to date sehingga di peneliti merasa perlu untuk terjun kelapangan untuk melakukan survei (2) Saat survei 
dilakukan, pengumpulan data sulit dilakukan dikarenakan adanya pandemi Covid-19, sehingga ada beberapa responden yang cenderung menolak untuk dimintai waktunya untuk wawancara. Oleh karena itu, penelitian selanjutnya sebaiknya harus merencanakan dengan baik pengumpulan data sehingga mampu mendeteksi UMKM bahan makanan dan pangan yang ada di kota Makassar termasuk yang tidak ada dalam database pemerintah daerah Kota Makassar. Dalam hal ini, pemerintah sebagai regulator harus mendorong UMKM menggunakan SIG melalui pelatihan tentang penggunaannya.

\section{DAFTAR PUSTAKA}

Aadila, A.E., Sideng, U. and Hasriyanti, H., 2021. Kontribusi Usaha Gogos Terhadap Pendapatan Rumah Tangga. LaGeografia, 19(2), pp.262-272.

Aryansah, J.E. and Mirani, D., 2020. Strategi Bertahan Usaha Mikro Kecil Dan Menengah Sektor Kuliner Di Masa Pandemi COVID19. Prosiding Applicable Innovation of Engineering and Science Research, 2020(1), pp.323329.

Brown, R. and Rocha, A., 2020. Entrepreneurial uncertainty during the Covid-19 crisis: Mapping the temporal dynamics of entrepreneurial finance. Journal of
Business Venturing Insights, 14, p.e00174.

Eggers, F., 2020. Masters of disasters? Challenges and opportunities for SMEs in times of crisis. Journal of Business Research, 116, pp.199208.

García-Vidal, G., Guzmán-Vilar, L., Sánchez-Rodríguez, A., MartínezVivar, R., Pérez-Campdesuñer, R. and Uset-Ruiz, F., 2020. Facing post COVID-19 era, what is really important for Ecuadorian SMEs?. International Journal of Engineering Business Management, 12, p.1847979020971944.

Kottika, E., Özsomer, A., Rydén, P., Theodorakis, I.G., Kaminakis, K., Kottikas, K.G. and Stathakopoulos, V., 2020. We survived this! What managers could learn from SMEs who successfully navigated the Greek economic crisis. Industrial Marketing Management, 88, pp.352-365.

Kuckertz, A., Brändle, L., Gaudig, A., Hinderer, S., Reyes, C.A.M., Prochotta, A., Steinbrink, K. and Berger, E.S., 2020. Startups in times of crisis-A rapid response to the COVID-19 pandemic. Journal of Business Venturing Insights, p.e00169.

Noviyanti, C., Erawati, W. and Lesmana, H., 2020. Rancang Bangun Pemetaan UMKM Kota Tegal Berbasis Sistem Informasi Geografis. Indonesian Journal on Software Engineering (IJSE), 6(1), pp.56-63.

Osiyevskyy, O., Shirokova, G. and Ritala, P., 2020. Exploration and 
exploitation in crisis environment: Implications for level and variability of firm performance. Journal of Business Research, 114, pp.227-239.

Pakaya, M.R., Musa, O., Karim, J. and Abdussamad, S., 2020. SIG Lokasi UMKM Berbasis Android. Jambura Journal of Electrical and Electronics Engineering, 2(2), pp.52-59.

Pressman, R.S., 2012. Rekayasa Perangkat Lunak Pendekatan Praktisi (Buku Satu). Yogyakarta: Andi.

Sharma, P., Leung, T.Y., Kingshott, R.P., Davcik, N.S. and Cardinali, S., 2020. Managing uncertainty during a global pandemic: An international business perspective. Journal of Business Research, 116, pp.188-192.

Susanty, A., Hartini, S., Puspitasari, D., Budiawan, W. and Hidayatullah, P., 2015. Design the Geographical Information System for Supplier Selection in Batik Industry

Syahputra, H. E., Purba, R., \& Sitompul, A. A. S. 2020. Pengaruh Persepsi Wajib Pajak Atas
Pemberlakuan Peraturan

Pemerintah Nomor 23 Tahun 2018, Pemahaman Perpajakan, Dan Sanksi Perpajakan Terhadap Kepatuhan Wajib Pajak Usaha Mikro, Kecil, Dan Menengah Di Kota Medan. Jurnal Mutiara Akuntansi, 5(2), 67-78.

Utami, M., \& Sunardi, D. 2020. Pemodelan Arsitektur Mobile Commerce Usaha Mikro Menggunakan EAP Dan Togaf ADM Framework. INTECOMS: Journal of Information Technology and Computer Science, 3(2), 290297.

Wibowo, N.S. and Selviyanti, E., 2021, March. The development of visualization of the small and medium industry distribution (IKM) using a web-based geographic information system. In IOP Conference Series: Earth and Environmental Science (Vol. 672, No. 1, p. 012083). IOP Publishing 